Systematic Botany (2005), 30(4): pp. 736-749

(c) Copyright 2005 by the American Society of Plant Taxonomists

\title{
A Plastid Gene Phylogeny of the Yam Genus, Dioscorea: Roots, Fruits and Madagascar
}

\author{
Paul Wilkin, ${ }^{1,6}$ Peter Schols, ${ }^{2}$ Mark W. Chase, ${ }^{1}$ Kongkanda Chayamarit, ${ }^{3}$ \\ Carol A. Furness, ${ }^{1}$ Suzy Huysmans, ${ }^{2}$ Franck Rakotonasolo, ${ }^{4}$ Erik SMEtS,${ }^{2}$ and \\ CHIRDSAK THAPYAI ${ }^{5}$ \\ ${ }^{1}$ Royal Botanic Gardens, Kew, Richmond, Surrey, TW9 3AB, U.K.; \\ ${ }^{2}$ Laboratory of Plant Systematics, Institute of Botany and Microbiology, K.U.Leuven, Kasteelpark Arenberg 31, \\ B-3001 Leuven, Belgium; \\ ${ }^{3}$ Forest Herbarium, 61 Phahonyothin Rd., Chatuchak, Bangkok 10900 Thailand; \\ ${ }^{4}$ Parc Botanique et Zoologique de Tsimbazaza, BP 4096, Antananarivo, Madagascar; \\ ${ }^{5}$ Biology Department, Faculty of Science, Naresuan University, Muang District, Phitsanulok 65000, Thailand \\ ${ }^{6}$ Author for correspondence (p.wilkin@rbgkew.org.uk) \\ Communicating Editor: Alan W. Meerow
}

\begin{abstract}
AвStract. Following recent phylogenetic studies of the families and genera of Dioscoreales, the identification of monophyletic infrageneric taxa in the pantropical genus Dioscorea is a priority. A phylogenetic analysis based on sequence data from the plastid genes $r b c L$ and $m a t K$ is presented, using 67 species of Dioscorea and covering all the main Old World and selected New World lineages. The analysis used 14 outgroup taxa, including Trichopus Gaertn., Tacca J.R. \& G. Forster, Stenomeris Planch., Burmannia L. and Thismia Griff. The main findings are: a) that a clade of rhizomatous taxa is sister to the rest of Dioscorea; b) the main Old World groups (such as the right-twining D. sect. Enantiophyllum) are monophyletic and c) there are two distinct lineages among the endemic Malagasy taxa. The consequences of the results for infrageneric classification of Dioscorea is considered, in particular the possibility of greatly simplifying the classifications of Knuth and Burkill. The results are also used to present novel hypotheses of character evolution in selected underground storage organ, inflorescence, fruit and seed characters and to discuss the origins of diversity in Dioscorea.
\end{abstract}

Dioscoreales are one of the most critical taxa in monocot systematics (Chase 2004 and references therein). Since the revolution in that field stimulated by the works of Huber (1969) and Dahlgren et al. (1985), the composition and relationships of the order have been the subject of an increasing level of study. In particular, the recent research of Caddick et al. (2002a; 2002b), using morphological and sequence data (from three genes), has demonstrated conclusively that the order comprises three families: Nartheciaceae, Burmanniaceae, and Dioscoreaceae. All are relatively small families (Kubitzki 1998). The largest of these in terms of number of species, Dioscoreaceae, comprise four genera (Caddick 2002a, 2002b). Three are monoecious and contain relatively few species. Tacca J.R. \& G. Forst. (at least ten species) has a unilocular ovary with many ovules; unlike most taxa in the family it does not climb but is a herb with a short stem. Stenomeris Planch. (two species) is a climber with a trilocular ovary with many ovules; it forms a three-winged, dehiscent capsule at least $25 \mathrm{~cm}$ long. Its flowers have an urceolate torus, with the stamens inserted towards the torus mouth and reflexed into it. The third monoecious genus, Trichopus Gaertn. (two species), possesses an ovary with two ovules in each of three locules, with up to five ovules aborting during the development of an irregularly dehiscent to indehiscent fruit. Its hypanthium is relatively small and not urceolate. Dioscorea L., the only dioecious genus, comprises ca. 450 species and has a trilocular ovary with two ovules per locule like Trichopus, but it lacks the complex arrangement of expanded stamen connectives and the "umbrella-like" stigma of that genus. With the generic and familial limits now better understood, the main systematic challenge in terms of biodiversity in Dioscoreales is Dioscorea. Dioscorea is also by far the most geographically widespread taxon, being almost ubiquitous in tropical and subtropical regions, with a few species being found in temperate areas. Species of Dioscorea are of significant importance as food (mainly in the form of their starchy tubers or "yams") and pharmaceuticals (e.g., corticosteroids and the contraceptive pill; Coursey 1967).

Dioscorea has presented a challenge to systematists for many years due to its great morphological diversity, dioecy, and small flowers. The first taxonomic treatments of significant numbers of species were those of Kunth (1850) and Uline (1898). The last complete monograph was published by Knuth (1924). Using a typically narrow "Pflanzenreich" species concept, he recognized ca. 600 species and divided them into four subgenera based on seed wing position, and then into 60 sections. However, when studied by a contemporary systematist, it is clear that many of Knuth's infrageneric taxa are clearly para- or even polyphyletic, for example the Old World compound-leafed species studied by Wilkin and Caddick (2000) and Wilkin (1999). Knuth divided these taxa into three sections and 51 species based on geography. The research cited 
above showed that there are approximately 18 species that can be be divided into two groups with clear morphological differences between them. Knuth even managed to place a single species in different sections under two different names (D. cochleari-apiculata De Wild. in sect. Botryosicyos (Hochst.) Uline and the synonymous D. stolzii R. Knuth. in sect. Lasiophyton Uline). Therefore, a reappraisal of Knuth's classification is needed.

The taxonomic ideas of Knuth were to some extent refined and improved by Burkill (Prain and Burkill 1936, 1938; Burkill 1939, 1951, 1952, 1960; Burkill and Perrier de la Bâthie 1950). He had a thorough knowledge of the tropical African and Asian species of Dioscorea and based his classification on an intimate knowledge of their morphology and ecology derived from many years of study of herbarium specimens and living plants. However, his knowledge of species from China, Madagascar, and the New World was restricted to herbarium material. In his infrageneric classification of the Old World taxa, Burkill avoided the rank of subgenus, and instead divided some 220 species into 23 sections. Like Knuth, he emphasized seed characters, but he added underground organ morphology and development and male inflorescence morphology to the character set used. This resulted in a classification more complex than that of Knuth, but one with a tendency to separate taxa using what now appear to be autapomorphies. Since 1960, the genus has been the subject of piecemeal floristic studies (e.g., Miège 1968; Milne-Redhead 1975; Tellez and Schubert 1994; N’Kounkou 1993; Miège and Sebsebe 1998; Ding and Gilbert 2000). The only complete taxonomic treatment was that of Huber (1998), in which the Knuth/Burkill system of classification was recapitulated, with all of the dioecious taxa of Dioscoreaceae included in subfamily Dioscoreoideae as "genera and genus-equivalent sections" (Huber's terminology). Although this idea was novel, the flaws inherrent in the treatments of Knuth and Burkill meant that many of the taxa used were not systematically sound, and the decision to raise them all to generic rank was subjective.

Our assessment of these studies of Dioscorea indicated that the systematics of the genus needed complete revision, and that the revision should use cladistic analysis of DNA sequence data for a significant number of species of the genus. The aim was to discover phylogenetic patterns of relationship and, in particular, to produce monophyletic infrageneric entities. Recently published examples of similar systematic research on large genera include Manos et al. (2001), Goldblatt et al. (2002), Perret et al. (2003), and Chase et al. (2003). As in Chase et al. (2003), it was hoped that this approach could also be helpful in beginning a new phase of searching for wild relatives of the main cultivated yams and medicine providers, and thus as- sist plant breeders, pathologists, phytochemists, and other applied biologists. A partial dataset for plastid $r b c L$ already existed from those taxa sampled by Caddick et al. (2002b), and mat $K$ was selected to provide further resolution following its successful use in other studies of monocot taxa (e.g., Fuse and Tamura 2000; Gravendeel et al. 2001; Ge et al. 2002). The main systematic hypotheses to be evaluated were the monophyly of Dioscorea and Knuth and Burkill's sections of Dioscorea, towards the aim of constructing a classification based on the principle of monophyly.

The generation of a phylogenetic tree for Dioscorea based on sequence data, and therefore independent of morphology, also allowed morphological character evolution to be explored. Similar studies have been undertaken, by, for example Cameron et al. (2001) for pollen morphology in Malphigiaceae and Allen et al. (2003) and Lamb Frye and Kron (2003) for selected macromorphological characters in Erythronium L. and Polygonaceae, respectively. Tuber morphology, stem twining direction, dioecy, and fruit/seed wing shape are among the most important characters in the systematics of Dioscorea. A broadly sampled tree also allows biogeographical hypotheses to be evaluated, such as Burkill's (1960) suggestion that there are two independent lineages in Madagascar; a group with deeply buried tubers and seeds winged at the base only and another with shallowly buried tubers at the end of long roots and seeds winged all round the margin. Overall, this study represents the first step in understanding the diversity of Dioscorea in a phylogenetic context.

\section{Materials AND MethodS}

Taxon Sampling. This study sampled 50 paleotropical species of Dioscorea, covering all of the main lineages evident from the infrageneric classifications of Knuth (1924) and Prain and Burkill (1960) and from the authors' own study of morphology (Table 1). Material from Thailand was particularly important in achieving this aim; the Thai flora contains almost all of the Asian species groups. There is also a sampling bias towards Madagascar. Both of these areas have high numbers of Dioscorea species per unit area: approximately one species per $12,000 \mathrm{~km}^{2}$ in Thailand and one per $14,500 \mathrm{~km}^{2}$ in Madagascar, while there is one species per $53,000 \mathrm{~km}^{2}$ in Zambia and one per $50,000 \mathrm{~km}^{2}$ in Malesia (Malaysia, Indonesia, the Philippines and New Guinea). Seventeen Neotropical species were included. Although it would be desirable to include more taxa from this region, the topology obtained was congruent with that of previous studies sampling more New World species (Raz, unpublished data; Bharathan et al. 2001). To significantly improve the sampling and support of the trees would mean two or three years more work, especially field collection. A total of 14 outgroup taxa were used from Tacca, Trichopus, and Stenomeris in Dioscoreaceae and Burmannia L. and Thismia Griff. in Burmanniaceae. Although they clearly nest within Dioscorea (Caddick et al. 2002b), some taxa formerly placed in Tamus L. and Rajania L. lack names in Dioscorea and are referred to by their published name with Dioscorea in parenthesis. New combinations will be made in due course.

DNA Extraction, Amplification, and Sequencing. DNA was extracted from c. $0.5-1.5 \mathrm{~g}$ fresh, $0.1-0.2 \mathrm{~g}$ silica-gel dried leaves (Chase and Hills 1991), or 0.1-0.2 g leaves from herbarium sheets using a 2X CTAB method modified from Doyle and Doyle (1987) 
TABLE 1. Sources of tDNA for taxa sequenced for $r b c \mathrm{~L}$ and matK., including voucher specimen details and GenBank accession numbers for sequences.

Burmannia biflora L., Chase 157 (NCU), USA, AY956483 (matK), AF206742 (rbcL). Burmannia longifolia Becc., Johns et al. 9157 (K), Indonesia (Papua), AY956484 (matK), AF307484 (rbcL). Burmannia madagascariensis Mart. \& Zucc., Caddick et al. 312 (K), Madagascar, AY956485 (matK), AF307486 ( rbcL)

Dioscorea c.f. adenocarpa Mart. ex Griseb., Wood 9178 (K), Bolivia, AY950686 (matK). Dioscorea alata Lour., Tamura E Fuse 10019 (Osaka City Univ. Botanic Garden), AB040208 (matK). Dioscorea alata Lour., Wilkin 1090 (K), Thailand, AY667098 (rbcL). Dioscorea alatipes Burkill \& H. Perr., Caddick et al. 334 (K), Madagascar, AY950687 (matK). Dioscorea alatipes Burkill \& H. Perr., Caddick et al. 333 (K), Madagascar, AY667099 (rbcL). Dioscorea amaranthoides C. Presl, Wood 12383 (K), Bolivia, AY950688 (matK). Dioscorea antaly Jum. \& H. Perr., Wilkin et al. 1103 (K), Madagascar, AY667100 (rbcL). Dioscorea antaly Jum. \& H. Perr., Wilkin et al. 1104 (K), Madagascar, AY956476 (matK). Dioscorea c.f. apurimacensis R. Knuth, Lewis 3210 (LOJA), Ecuador, AY956477 (matK), AY667101 (rbcL). Dioscorea arachidna Prain \& Burkill, Wilkin et al. 862 (K), Thailand, AY956478 (matK), AF307468 (rbcL). Dioscorea arcuatinervis Hochr., Caddick et al. 310 (K), Madagascar, AY956479 (matK), AY667102 (rbcL). Dioscorea bemarivensis Jum. \& H. Perr., Caddick 340 (K), Madagascar, AY667103 (rbcL). Dioscorea bemarivensis Jum. \& H. Perr., Wilkin et al. 1124 (K), Madagascar, AY956480 (matK). Dioscorea birmanica Prain \& Burkill, Thapyai et al. 409 (BKF), Thailand, AY956481 (matK), AY667104 (rbcL). Dioscorea brachybotrya Poepp., Rudall 1/97 (K), Chile, AY956482 (matK), AF307469 (rbcL). Dioscorea brevipetiolata Prain \& Burkill, Wilkin et al. T964 (K), Thailand, AY956486 (matK), AY667105 (rbcL). Dioscorea buchananii Benth., Bingham et al. 10290 (K), Zambia, AY956487 (matK), AY904790 (rbcL). Dioscorea bulbifera L., Foster et al. 12 (K), Madagascar (RBG Kew cult. 1998-533), AY956488 (matK), AY904791 (rbcL). Dioscorea calcicola Prain \& Burkill, Wilkin et al. 814 (K), Thailand, AY956489 (matK). Dioscorea cirrhosa Lour., Thapyai 375 (BKF), Thailand, AY904792 (rbcL). Dioscorea communis (L.) Caddick \& Wilkin, Chase 536 (K), UK, AY956490 (matK), AF307474 (rbcL). Dioscorea convolvulacea Schltdl. \& Cham., Chase 197 (NCU), Trinidad, AY956491 (matK), AJ235805 ( $r b c L)$. Dioscorea coriacea Humb. \& Bonpl. ex Willd., Lewis 3220 (LOJA), Ecuador, AY956492 (matK). Dioscorea daunea Prain \& Burkill, Thapyai et al. 518 (BKF), Thailand, AY956493 (matK), AY904793 (rbcL). Dioscorea decipiens Hook. f., Wilkin et al. 861 (K), Thailand, AY956494 (matK). Dioscorea decipiens Hook. f., Wilkin 860 (K), Thailand, AF307454 (rbcL). Dioscorea dumetorum (Kunth) Pax, Wilkin 761 (K), Malawi (RBG Kew cult. 1994-1455), AY956495 (matK), AF307464 (rbcL). Dioscorea elephantipes (L'Hér.) Engl., UCI Arb. 6773 (NCU), Cultivated, AY956496 (matK), AF307461 (rbcL). Dioscorea esculenta (Lour.) Burkill, Wilkin et al. 995 (K), Thailand, AY956497 (matK), AY904794 (rbcL). Dioscorea fandra Jum. \& H. Perr, Caddick et al. 324 (K), Madagasar, AY956498 (matK), AY904795 (rbcL). Dioscorea galeottiana Kunth, Tellez 13090 (MEXU), Mexico, AY956499 (matK), AY904796 (rbcL). Dioscorea gillettii Milne-Redh., Vollesen 61 (K), Kenya, AY956500 (matK), AY904797 (rbcL). Dioscorea glabra Roxb., Wilkin et al. 874 (K), Thailand, AY956501(matK), AF307456 (rbcL). Dioscorea glomerulata Hauman, Wood 8065 (K), Bolivia, AY957586 (matK). Dioscorea hamiltonii Prain \& Burkill, Wilkin et al. 886 (K), Thailand, AY957587 (matK), AF307465 (rbcL). Dioscorea hexagona Jum. \& H. Perr., Wilkin et al. M960 (K), Madagascar, AY957588 (matK), AY904798 (rbcL). Dioscorea hispida Dennst., Wilkin et al. 855 (K), Thailand, AY957589 (matK), AF307463 (rbcL). Dioscorea inopinata Prain \& Burkill, Thapyai et al. 513 (BKF), Thailand, AY957590 (matK), AY904799 (rbcL). Dioscorea karatana Wilkin, Wilkin et al. 947A (K), Madagascar (RBG Kew cult. 1999-2988), AY957591(matK). Dioscorea lagoa-santa Uline ex R. Knuth, Wood 8182 (K), Bolivia, AY957592(matK). Dioscorea lanata Balf. f., Miller 10423 (E), Socotra, AY957593 (matK), AF307458 (rbcL). Dioscorea larecajensis Uline ex R. Knuth, Wood 9960 (K), Bolivia, AY957594 (matK). Dioscorea longirhiza Caddick \& Wilkin, Tellez 13081 (MEXU), Mexico, AY957595 (matK), AF307473 (rbcL). Dioscorea maciba Jum. \& H. Perr., Caddick et al. 318 (K), Madagascar, AY957596 (matK), AY904800 (rbcL). Dioscorea mcvaughii B.G. Schub., Tellez 13080 (MEXU), Mexico, AY957597(matK), AF307460 (rbcL). Dioscorea membranacea Pierre, Wilkin et al. 878 (K), Thailand, AY957598 (matK), AF307467 (rbcL). Dioscorea namorokensis Wilkin, Wilkin et al. 1123 (K), Madagascar, AY957599 (matK). Dioscorea nipponica Makino, Chase 6225 (K), RBG Kew cult. 1969 19664, AY957600 (matK), AF307455 (rbcL). Dioscorea ovinala Baker, Wilkin et al. 1108 (K), Madagascar, AY972481 (matK). Dioscorea oryzetorum Prain \& Burkill, Thapyai 464 (BKF), Thailand, AY972482 (matK), AY904801 (rbcL). Dioscorea pentaphylla L., Wilkin et al. $888(\mathrm{~K})$, Thailand, AY972483 (matK), AF307470 (rbcL). Dioscorea petelotii Prain \& Burkill, Wilkin et al. 1023 (K), Thailand, AY973484 (matK), AY904802 (rbcL). Dioscorea prazeri Prain \& Burkill, Wilkin et al. 1075 (K), Thailand, AY973485 (matK), AY904803 (rbcL). Dioscorea preussii Pax, Davis 3019 (K), Cameroon, AY973486 (matK). Dioscorea pseudo-nitens Prain \& Burkill, Thapyai et al. 452 (BKF), Thailand, AY973487 (matK). Dioscorea pyrenaica Bubani \& Bordère ex Gren., Sandwith 4745 (K), Spain, AF307471 (rbcL). Dioscorea rockii Prain \& Burkill, Wilkin et al. 1036 (K), Thailand, AY972488 (matK), AY939882 (rbcL). Dioscorea sansibarensis Pax, Wilkin et al. 973 (K), Madagascar (RBG Kew cult. 1998-525), AY972489 (matK), AY939883 (rbcL). Dioscorea schimperiana Hochst. ex Kunth, Wilkin et al. 762 (K), Malawi (RBG Kew cult. 1995-1450), AY972490 (matK), AF307466 (rbcL). Dioscorea soso Jum. \& H. Perr., Wilkin et al. 1102 (K), Madagascar, AY939884 (rbcL). Dioscorea soso Jum. \& H. Perr., Wilkin et al. 1106 (K), Madagascar, AY972491 (matK). Dioscorea subhastata Vell., Wood 9093 (K), Bolivia, AY972492 (matK). Dioscorea sylvatica Ecklon, Chase 6184 (K), RBG Kew Cult. 1994-796, AY972826 (matK), AF307462 (rbcL). Dioscorea c.f. tanalarum H. Perr., Caddick et al. 302 (K), Madagascar, AY972827 (matK), AY939885 (rbcL). Dioscorea tentaculigera Prain \& Burkill, Thapyai 436 (BKF), Thailand, AY972828 (matK), AY939886 (rbcL). Dioscorea trichantha Baker, Wilkin et al. 1153 (K), Madagascar, AY972829 (matK), AY939887 (rbcL). Dioscorea wallichii Hook. f., Wilkin et al. 1072 (K), Thailand, AY973830 (matK), AY939888 (rbcL). Dioscorea zingiberensis C.H. Wright, TCMK 244 (K), China, AY973831 (matK), AY939889 (rbcL). Dioscorea sp. A, Wood E Guzman 17511 (K), Bolivia, AY973832 (matK). Dioscorea sp. B, Lewis 3177 (LOJA), Ecuador, AY973833 (matK). Dioscorea sp. C, Wood 8032 (K), Bolivia, AY973834 (matK). Rajania (Dioscorea) cordata L., Axelrod 8407 (UPR), Cuba, AY973835 (matK), AF307472 (rbcL)

Stenomeris borneensis Oliv., BRUN 19173 (K), Brunei, AF307475 (rbcL). Stenomeris borneensis Oliv., BRUN 19174 (K), Brunei, AY973836 (matK)

Tacca artocarpifolia Seem., Caddick 305 (K), Madagascar, AF307481 (rbcL). Tacca chantrieri André, Chase 175 (NCU), Cultivated, AY973837 (matK), AJ286561 (rbcL). Tacca integrifolia Ker Gawl., Boyce 1074 (K), Thailand, AY973838 (matK), AF307478 (rbcL). Tacca leontopetaloides (L.) O. Kuntze, Wilkin et al. 817 (K), Thailand, AY973839 (matK), AF307480 (rbcL). Tacca palmata Blume, Boyce 1082 (K), RBG Kew cult. 1996-1257, AY973840 (matK), AF307479 (rbcL). Tacca palmatifida Baker, Chase 1377 (K), Cult. Bogor XI.B.VI.134, AY973841 (matK), AY939890 (rbcL). Tacca plantaginea (Hance) Drenth, Leiden B.G. 920520 (L), Cult., AY973842 (matK), AF307483 (rbcL) 
TABLE 1. Continued.

Tamus (Dioscorea) edulis Lowe, Chase 3425 (K), Canary Is., AY973843 (matK), AY939891 (rbcL)

Thismia rodwayi F. Muell., Garnock-Jones 2218 (WELTU), New Zealand, AY939892 (rbcL)

Trichopus sempervirens (H. Perr.) Caddick \& Wilkin, Caddick 304 (K), Madagascar, AF307476 (rbcL). Trichopus sempervirens (H. Perr.) Caddick \& Wilkin, Wilkin 948 (K), Madagascar, AF973844 (matK). Trichopus zeylanicus Gaertn., Caddick 346 (K), Sri Lanka, AF307477(rbcL). Trichopus zeylanicus Gaertn., Chase 16354 (K), Sri Lanka, AY973845 (matK)

DNA was precipitated in 2.5 vol. ethanol or $2 / 3$ vol. isopropanol for herbarium dried specimens. DNA samples were purified on $\mathrm{CsCl}_{2}$ /ethidium bromide gradients $(1.55 \mathrm{~g} / \mathrm{ml})$ and stored at $-20^{\circ} \mathrm{C}$. For problematic samples, a $150 \mu \mathrm{l}$ aliquot of DNA was cleaned and concentrated using a 'Wizard' mini-column, following manufacturer's instructions (Promega, Crawley, West Sussex, UK).

Amplification of $r b c L$ was undertaken in two halves using the primers 1F, 724R, 636F, and 1360R as described in Caddick et al. (2002b). These four primers were also used for sequencing.

Amplification of matK was carried out in the same manner as Salazar et al. (2003), using the $50 \mu \mathrm{l}$ reaction method with PCR master mix. In addition to the $-19 \mathrm{~F}$ and $2 \mathrm{R}$ primers used to amplify the whole matK-trnK region, the internal primers 390F and 1326R were also used for some problematic amplifications and all sequencing (Cuénoud et al. 2002). Most taxa were amplified successfully with a premelt of 2 mins 30 secs at $94^{\circ} \mathrm{C}$, followed by 28 cycles of 1 min denaturation at $94^{\circ} \mathrm{C}, 45$ secs annealing at $52^{\circ} \mathrm{C}, 2$ mins 30 secs extension at $72^{\circ} \mathrm{C}$, plus a final extension of 7 mins at $72^{\circ} \mathrm{C}$. For problem taxa, a $4 \mathrm{~min}$ premelt was used, followed by 30 cycles of $1 \mathrm{~min}$ at $94^{\circ} \mathrm{C}, 1 \mathrm{~min}$ at $52^{\circ} \mathrm{C}, 2$ mins $30 \mathrm{secs}$ at $72^{\circ} \mathrm{C}$, and a 7 minute final extension at $72^{\circ} \mathrm{C}$. in these cases, each $50 \mu \mathrm{l}$ reaction contained $6 \mu \mathrm{l} 25 \mathrm{mmol} / \mathrm{L} \mathrm{MgCl}_{2}, 5 \mu \mathrm{l}$ 10x Mg-free DNA polymerase buffer (Promega, Madison, Wisconsin, USA), $2 \mu l 0.4$ $\%$ bovine serum albumen (BSA), $1 \mu 110 \mathrm{mmol} / \mathrm{L}$ dNTP, $0.7 \mu \mathrm{l}$ each primer, $0.5 \mu 15$ units/ $\mu 1$ Taq DNA-polymerase (Promega), 2 $\mu l$ template DNA and $32.1 \mu \mathrm{ldd \textrm {d } _ { 2 }} 0$.

All PCR products were cleaned using 'Wizard' mini-columns, following manufacturer's instructions (Promega, Crawley, West Sussex, UK). Amplification products were sequenced directly with modified dideoxy cycle sequencing with dye terminators according to the manufacturers' protocol (Applied Biosystems, ABI, Warrington, Cheshire, UK). Sequencing reactions were run on an $\mathrm{ABI}$ 377 automated sequencer according to the manufacturer's protocols. Sequence files were edited and assembled using Sequence Navigator and Autoassembler (ABI) or Sequencher 4.1 (Gene Codes Corp., Ann Arbor, Michigan, USA). Low numbers of insertions and deletions in $m a t K$ and their absence in $r b c L$ made alignment by eye possible. The part of the trnK intron sequenced was not used in analyses. Coding of indels as presence/absence characters was not undertaken. The matrix is available on email request from PW and MWC. All sequences have been submitted to GenBank and the aligned data matrix to TreeBASE (study accession S1370, matrix accessions M2432).

Analyses. Parsimony analyses were carried out using PAUP* $4.0 \mathrm{~b} 10$ software (Swofford 2001). For $r b c L$, missing data at the $3^{\prime}$ and $5^{\prime}$ ends were excluded such that only base pair positions 311398 were used. Similarly, base pair positions 1-32 were omitted from the $m a t K$ analysis. All characters were treated as equally weighted. The species of Burmannia and Thismia (Table 1) were specified as the outgroup following the tree topology obtained in Caddick et al. (2002b). A heuristic search consisted of 1000 random taxon-additions and tree-bisection-reconnection (TBR) branch swapping but holding no more than 10 trees per replicate to avoid swapping on large numbers of suboptimal trees, with the MulTrees option in effect. Branches were collapsed if minimum length $=0$ ("amb-"). The trees generated were then used in a second phase of analysis with no tree limit in effect. Support for clades was estimated using the bootstrap (Felsenstein 1985), which consisted of 1000 bootstrap replicates, simple taxon addition, and TBR branch swapping. Again, no more than 10 trees were saved per replicate. Groups were retained with bootstrap percentages (BP) $>50 \%$.
Morphological Character Optimization. In addition to the DNA datasets, the following macromorphological characters and states were optimized onto the tree presented here using MacClade 4.05 (Maddison and Maddison 2002); the characters were not not used in the combined analysis because there are too few of them to have an effect.

1. Underground parts rhizomatous (0), perennial tuber (1), annually replaced tuber (2).

2. Plants with all flowers hermaphrodite (0), plants dioecious (1) (terminology follows Richards 1986)

3. Stem twining direction left (0), right (1)

4. Fruit a dry, thin-walled capsule (0), fruit a fleshy berry, at least until submature (1), fruit a leathery berry (2).

5. Seed winged all round margin (0), seed wing basal only (1), seed wing apical only (2), seed winged only at base and apex (3).

Character state data were obtained from the authors' personal observations. All of the characters were important parts of the infrageneric classifications of Dioscorea of Knuth (1924) and Burkill (1960). Underground part morphology was used to delimit sections extensively by Burkill, but only to a very limited extent by Knuth. Both used dioecy as a character to delimit Dioscorea. Stem twining direction exhibited a particularly clear division between two groups of Burkill's Old World sections. Fruit morphology was used to separate Rajania and Tamus from Dioscorea since the era of Linnaeus. Burkill (1960) also used the presence of fleshy capsule walls to define D. sect. Pachycapsa Burkill \& H. Perr., and seed wing position used by all authors as far back as Kunth (1850) as a generic or subgeneric character. Thus the character optimization was was seen as a valuable exercise at this point in our understanding of Dioscorea phylogenetics, particularly for assessing the congruence of characters used to define existing infrageneric taxa with the trees obtained in this study, or at least those parts with good support.

\section{RESUlTS}

Separate analyses of the $r b c L$ and $m a t K$ datasets were undertaken first. Tree statistics for these analyses are shown in Table 2. Taxa with missing data from entire regions were excluded from the single gene analyses (D. c.f. adenocarpa, D. amaranthoides, D. calcicola, D. coriacea, D. glomerulata, D. karatana, D. lagoa-santa, D. larecajensis, D. namorokensis, D. ovinala, D. sp. A, D. sp. B, D. sp. C, D. subhastata, and Burmannia biflora for $r b c L$; D. cirrhosa, D. pyrenaica, Thismia rodwayi, and Tacca artocarpfolia for matK). No hard incongruence (i.e., incongruence with high $\mathrm{BP}$ ) was observed in the bootstrap consensus trees obtained for the two genes, so the datasets were combined. This approach is the same as that followed in, for example, Whitten et al. (2000), Reeves et al. (2001) and Simpson et al. (2003). One tree from the combined plastid gene analysis is presented in Fig. 1. This is based on a final alignment of 3,321 sites, of which 1,041 are variable and $680(20.5 \%)$ po- 
TABLE 2. Tree statistics for analyses of the $m a t K, r b c L$, and combined datasets.

\begin{tabular}{|c|c|c|c|c|c|c|c|}
\hline Gene & $\begin{array}{l}\text { No. of } \\
\text { sites }\end{array}$ & $\begin{array}{l}\text { No. potentially } \\
\text { phylogenetically } \\
\text { informative }\end{array}$ & $\begin{array}{l}\% \text { potentially } \\
\text { phylogenetically } \\
\text { informative }\end{array}$ & Tree length & $\begin{array}{l}\text { No. of } \\
\text { trees }\end{array}$ & CI & RI \\
\hline$r b c L$ & 1368 & 187 & 13.7 & 608 & $\begin{array}{c}\text { More than } \\
30000\end{array}$ & 0.59 & 0.76 \\
\hline matK & 1953 & 493 & 25.2 & 1345 & $\begin{array}{c}\text { More than } \\
30000\end{array}$ & 0.70 & 0.83 \\
\hline $\begin{array}{c}\text { Combined } \\
\text { dataset }\end{array}$ & 3321 & 680 & 20.5 & 1977 & 15868 & 0.66 & 0.81 \\
\hline
\end{tabular}

tentially phylogenetically informative. The total number of equally most parsimonious trees generated was 15,868 , each with 1,977 steps, $\mathrm{CI}=0.66$ and $\mathrm{RI}=0.81$. Figure 1 also shows those branches that collapse in the strict consensus tree (dashed lines) and identifies nodes with weak or strong bootstrap support. Dioscorea, including all of the dioecious taxa (as in Caddick et al. 2002b) is resolved as monophyletic within Dioscoreaceae $(\mathrm{BP}=95)$. Resolution among the genera of Dioscoreaceae is unclear. Within Dioscorea, the base of the tree and the early branching clades (A) are mostly strongly supported. It is clear that D. sect. Stenophora Uline is sister to the rest of Dioscorea (the clade labelled Stenophora); its monophyly has BP 100, and its sister clade BP 92. There are also two strongly supported New World clades (NW) that are not each other's closest relatives (BP 88). The spine of the tree has much shorter branch lengths above the base. Several, such as the African southern and montane clade (Afr.) and the European clade (EU) form a polytomy with the larger NW clade in the strict consensus tree from the combined analysis. In the African southern and montane clade, D. sylvatica and D. elephantipes are sister-species with strong bootstrap support. Both were once placed in the genus Testudinaria Burch, and they share large, perennial, woody tubers.

The remaining clade, from $D$. tentaculigera to D. oryzetorum (B), comprises entirely Old World taxa, with the sole exception of Rajania (Dioscorea) cordata. Its monophyly has weak support (BP 53). Overall, the degree of resolution of these taxa by matK and $r b c L$ is mixed, with a significant polytomy at the node above D. tentaculigera and a number of unresolved taxa, but two well-supported subclades within the B clade can be identified (Malagasy and Enantiophyllum). Dioscorea tentaculigera is sister to all of the B clade taxa, on a rather long branch. The first of the two main subclades is one wholly comprising endemic species from Madagascar (Malagasy; BP 91). It can also be seen that it is further divided into two strongly supported sister clades. The first, with three taxa, is relatively divergent from the rest. The accession of D. c.f. tanalarum, which came from eastern Madagascar, but not littoral forest, may be $D$. arcuatinervis or a close relative, but unfortunately was sterile. The second clade has $D$. fandra sis- ter to the rest of its many taxa and conspicuously short internal branches. A compound-leafed clade (CL) was recovered, but it lacks BP support. The two main compound-leafed groups each have an entire-leafed sister species: $D$. antaly in the case of $D$. dumetorum/D. hispida and D. bulbifera for D. arachidna/D. pentaphylla. The final major subclade of the B clade is D. sect. Enantiophyllum (Enantiophyllum; BP 98). The African species D. schimperiana is sister to the rest of the clade. Like the Malagasy clade, the internal branches are short. It should be noted that in the optimizations of the morphological characters (Figs. 2-5), state changes occur wholly or mainly at the better supported nodes. The clade comprising D. birmanica (Birmanica) and its possible allies is not robust. In some trees D. petelotii, D. pseudonitens, and D. esculenta also fall within this clade, but all of these taxa collapse to the base of the B clade in the strict consensus tree, as does Rajania (Dioscorea) cordata.

\section{DISCUSSION}

Dioscorea and D. sect. Stenophora. The sister relationship of D. sect. Stenophora to the rest of Dioscorea has appeared in every analysis of Dioscorea to date, highlighting the pivotal position of the section in the systematics of the genus. This study is the first in which there is BP support for this topology. Dioscorea sect. Stenophora was divided into two taxa by Knuth (1924), D. sect. Eustenophora R. Knuth and D. sect. Macropoda Uline. Burkill $(1936,1960)$ united them, and suggested their importance in the evolution of the genus. What he could not have known was their degree of sequence divergence from the rest of Dioscorea, indicated by the data from the two plastid genes studied here (Fig. 1). All 20-25 species of this taxon have underground parts consisting solely of a branching horizontal rhizome. In this respect they are similar to Trichopus sempervirens and several members of Tacca. Figure 2 shows underground part morphology optimized onto the tree in Fig. 1. The optimization of flower sex is shown in Fig. 3. Dioecy is clearly a synapomorphy for the genus Dioscorea. However, several species of $D$. sect. Stenophora display polymorphism for this character: a few immature capsules occurring on a male plant, or male flowers on a female inflorescence (e.g., 


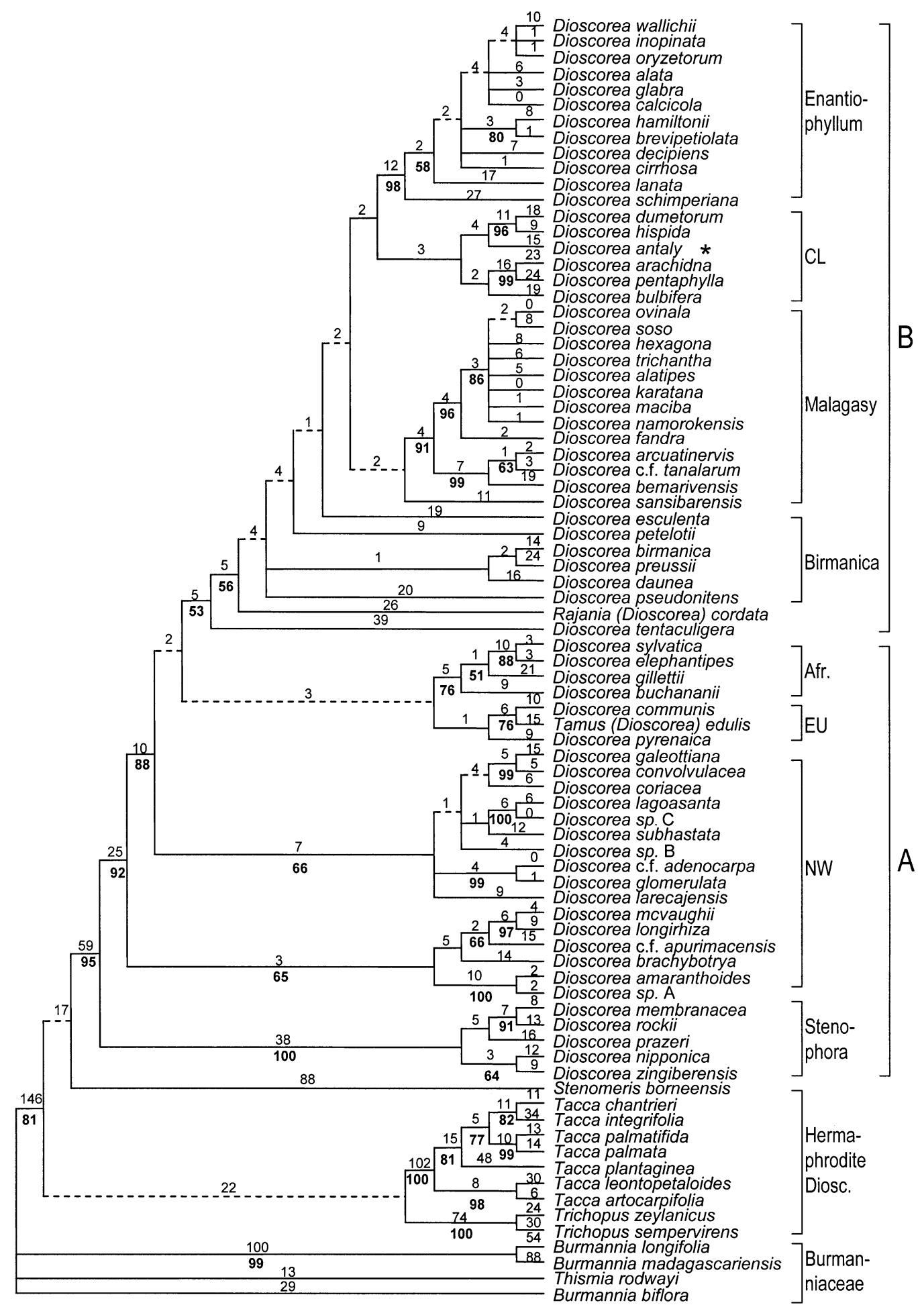

FIG. 1. One of the 15868 trees from the combined $r b c L$ and matK analysis of Dioscorea. Figures above lines are branch lengths (DELTRAN optimization) and below (bold) bootstrap percentages (BP). Dashed lines indicate the nodes that collapse in the strict consensus tree. $\mathrm{NW}=\mathrm{New}$ World, $\mathrm{EU}=$ Europe, $\mathrm{CL}=$ compound-leafed, $\mathrm{A}=$ early branching clades, $\mathrm{B}=\mathrm{B}$ clade. $D$. antaly (marked *) is the only endemic species from Madagascar that does not fall in the Malagasy clade. 


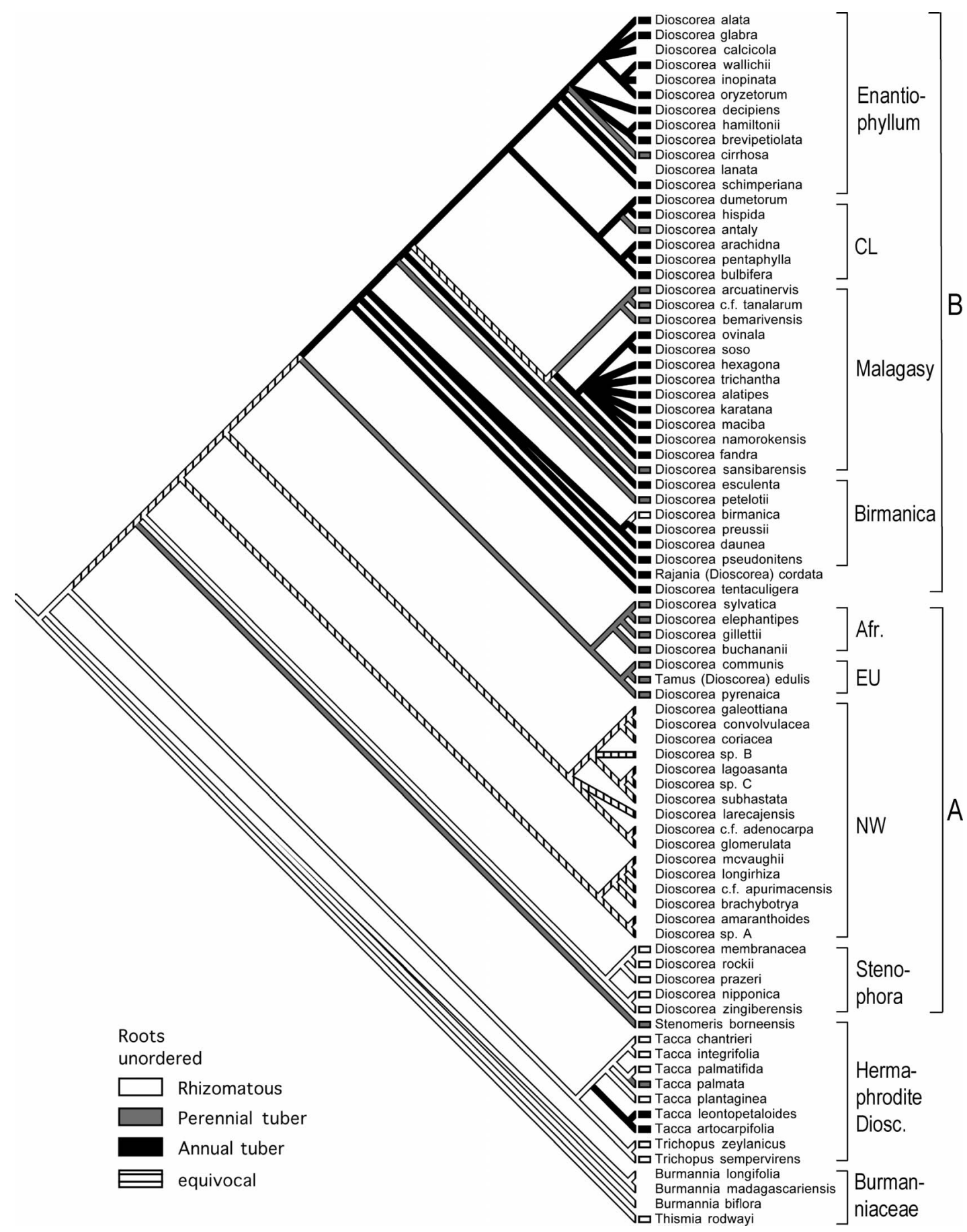

FIG. 2. Underground part morphology optimized onto one of the 15868 most parsimonious trees. Missing data are indicated by the lack of a shaded box at the branch tip.

D. rockii [pers. obs.] and D. zingiberensis [M.G. Gilbert pers. comm.]). Unstable dioecy has also been reported in a few Neotropical species such as $D$. convolvulacea (Sosa et al. 1987), which are also members of early branching clades. This indicates that the developmen- tal mechanisms that control floral development are not as stable in these clades as in the rest of Dioscorea. As currently understood, the species of $D$. sect. Stenophora are restricted to temperate and subtropical areas of the northern hemisphere, through the Caucasus, Himala- 


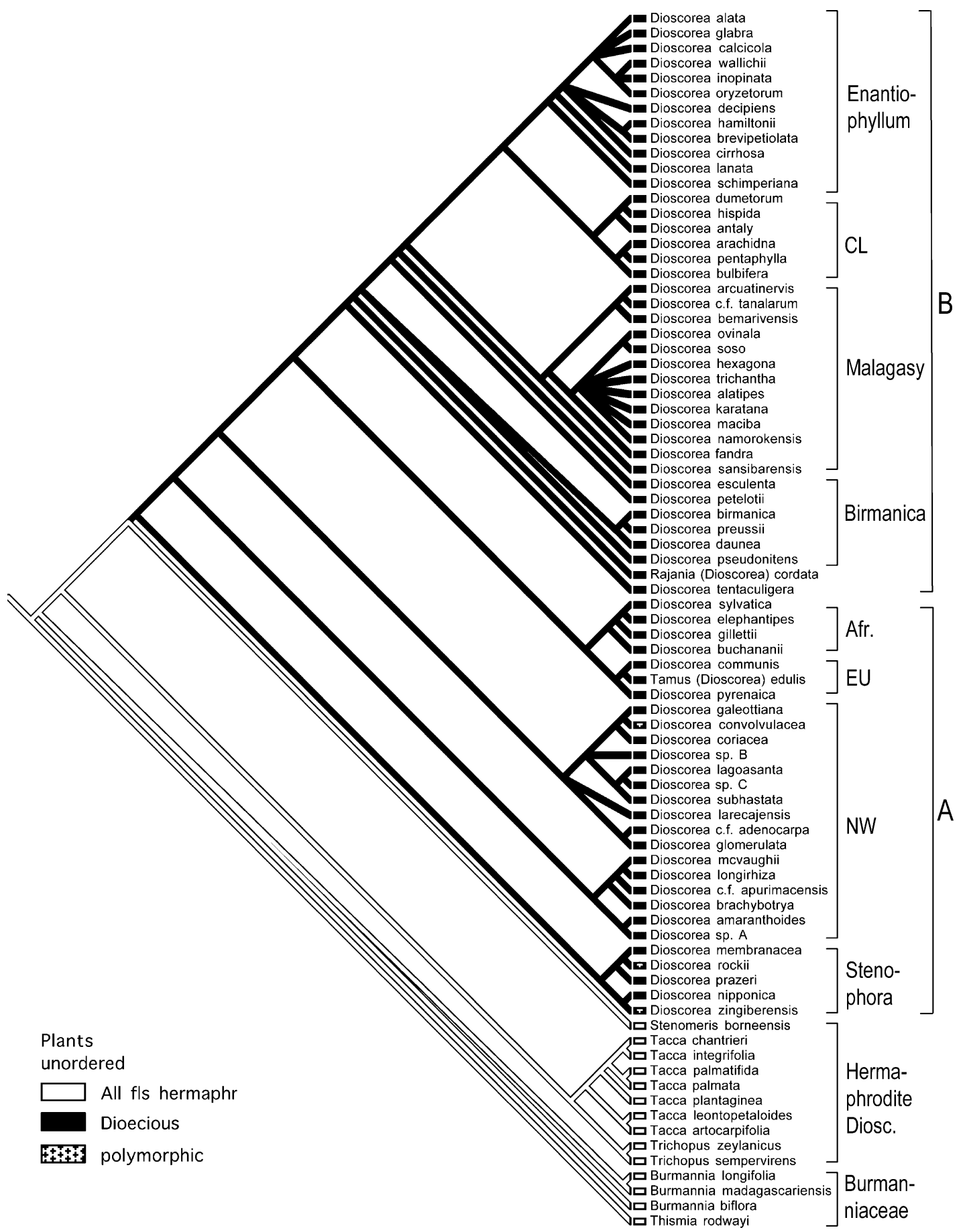

Fig. 3. Flowers hermaphrodite/plants dioecious optimized onto one of the 15868 most parsimonious trees. Missing data are indicated by the lack of a shaded box at the branch tip.

yas, China and Japan to North America. Their southernmost point of distribution is probably the Isthmus of Kra in Thailand. Two more species may belong to this group (D. ridleyi Prain \& Burkill from Sarawak and D. palawana Prain \& Burkill from the Philippines) but unfortunately they are not included. They are rare, and their underground parts are not fully known (Wilkin et al. 2002). The diversity and pantropical distribution of Dioscorea as a whole (ca. 450 species) when compared with the restricted distribution and fewer spe- 
cies of $D$. sect. Stenophora suggest that the origins of the diversity may lie in the combination of dioecy and tuber possession, but not dioecy alone. Burkill (1960) suggested that the evolution of the ability to inhabit niches with limited or more seasonal rainfall was the most important factor promoting diversity in Dioscorea, not dioecy. Dioscorea is light-demanding, but of insufficient stature to be a major element of wet tropical forests. Consequently selection favoured forms that could thrive in drier, more open habitats.

New World Taxa. The tree topology in Fig. 1 with two monophyletic stem clades of New World taxa is similar to that found by Bharathan et al. (2001) for trnL-F and $n d h F$. Clearly, much greater sampling of New World taxa is necessary to increase confidence in the results obtained. Nevertheless, it appears that only Rajania falls among the otherwise exclusively Old World B clade. Research by Lauren Raz (pers. comm.) indicates that a small number of Neotropical Dioscorea species allied to Rajania also nest there. Analysis of the combined data obtained by Raz and in this study is already planned. Figure 4 shows that the right-twining (dextrorse in the sense of Burkill 1960) habit has arisen at least twice in Dioscorea, with both clades and their positions having weak or strong bootstrap support (Fig. 1). Further sampling may show multiple New World origins of right-twining, but it is present in only one clade here. The right-twining habit has clearly only evolved once in the Old World (see Enantiophyllum below). Underground part morphology (Fig. 2) is an area in which the New World taxa are data-deficient; D. convolvulacea may be rhizomatous (Sosa et al. 1987), but field-based research on underground part morphology is desirable.

Southern and Montane Africa. The biogeographical link between the species in this clade (Afr.) species makes further study particularly important. They have not previously been thought to form a taxon.

European Taxa. This clade (EU) is not present in the combined strict consensus tree, perhaps because $D$. pyrenaica has only been sequenced for $r b c L$ (we need to collect more extractable material). It is found in the strict consensus tree for $r b c L$ alone, although only the D. communis/Tamus (Dioscorea) edulis clade has weak bootstrap support. It is mainly of interest because the genus Tamus was separated from Dioscorea on the basis of it having a fleshy berry, whereas Dioscorea has a dry capsule. Berry-like fruits are also encountered in at least two other lineages in Madagascar, although in both $D$. ovinala and D. antaly (Fig. 1) the thick-walled fruit dries out and dehisces in the final stages of development. The first author has also seen a herbarium specimen from Bolivia that appeared to have a berry, although it was not fully mature and the fruits had been dried rather than preserved in spirit. Thus, this shift of dispersal strategy in Dioscorea does not merit generic segregation. Tacca, with many fewer species than Dioscorea, has much greater diversity in fruit morphology.

B Clade. This clade is the most economically important within Dioscorea because the major cultigens and many of the edible wild species are found in this clade. This is probably because many of the species in this part of the tree have annual tubers, in marked contrast to the clades at the basal nodes, which usually have perennial tubers (Fig. 2). Unfortunately, information on the underground parts of the New World taxa of Dioscorea is lacking. It is probable, based on the optimization in Fig. 2, that tuber evolution is an important source of diversity within the B clade of Dioscorea. For example, the compound-leafed species (CL clade) studied by Wilkin and Caddick (2000) have a diverse array of tuber forms. The low levels of molecular divergence among some of the B clade $(D$. tentaculigera to $D$. oryzetorum) shown by the short branch lengths suggests that the limit of resolution of the two genes studied has been reached for these taxa. Branch lengths for $D$. tentaculigera and Rajania (Dioscorea) cordata are noticeably higher than for other taxa in this part of the tree. The former in particular appears to be in a systematically isolated position. Prain and Burkill (1936) tentatively placed D. tentaculigera in D. sect. Stenophora on the basis of its capsule shape, though they had not seen its underground organs, but this study and its paired, vertically oriented tubers (Thapyai, pers. obs.) both contradict this.

Madagascar. One of the clades nested within the B clade comprises endemic taxa from Madascar (Malagasy). Only one endemic species from Madagascar does not fall in this clade, $D$. antaly. The clade of endemic Malagasy species is composed of two well-supported sister subclades. The first of these (D. bemarivensis-D. c.f. tanalarum) has seeds with a wing all round the margin (Fig. 5; the plesiomorphic condition). The underground parts of $D$. arcuatinervis and $D$. bemarivensis appear similar, with long, terete tubers that spread horizontally through the soil and have swollen apices. Dioscorea bemarivensis is from western, seasonally dry forests, whereas $D$. arcuatinervis is found in littoral forest of the eastern coast, which receives yearround rainfall. The second subclade comprises species with basally winged seeds, in which rotational flight appears to improve dispersal distance when compared with the gliding flight of seeds that are winged all round the margin (Burkill 1960). This adaptive change appears to have multiple evolutionary origins (Fig. 5). All species of the second subclade possess two vertically oriented tubers (one shrinking, one growing) of even thickness. As in the D. bemarivensis-D. c.f. tanalarum clade, $D$. fandra, which is sister to the rest of the second clade, is a species from the dry southwest. The low levels of molecular divergence within this clade 


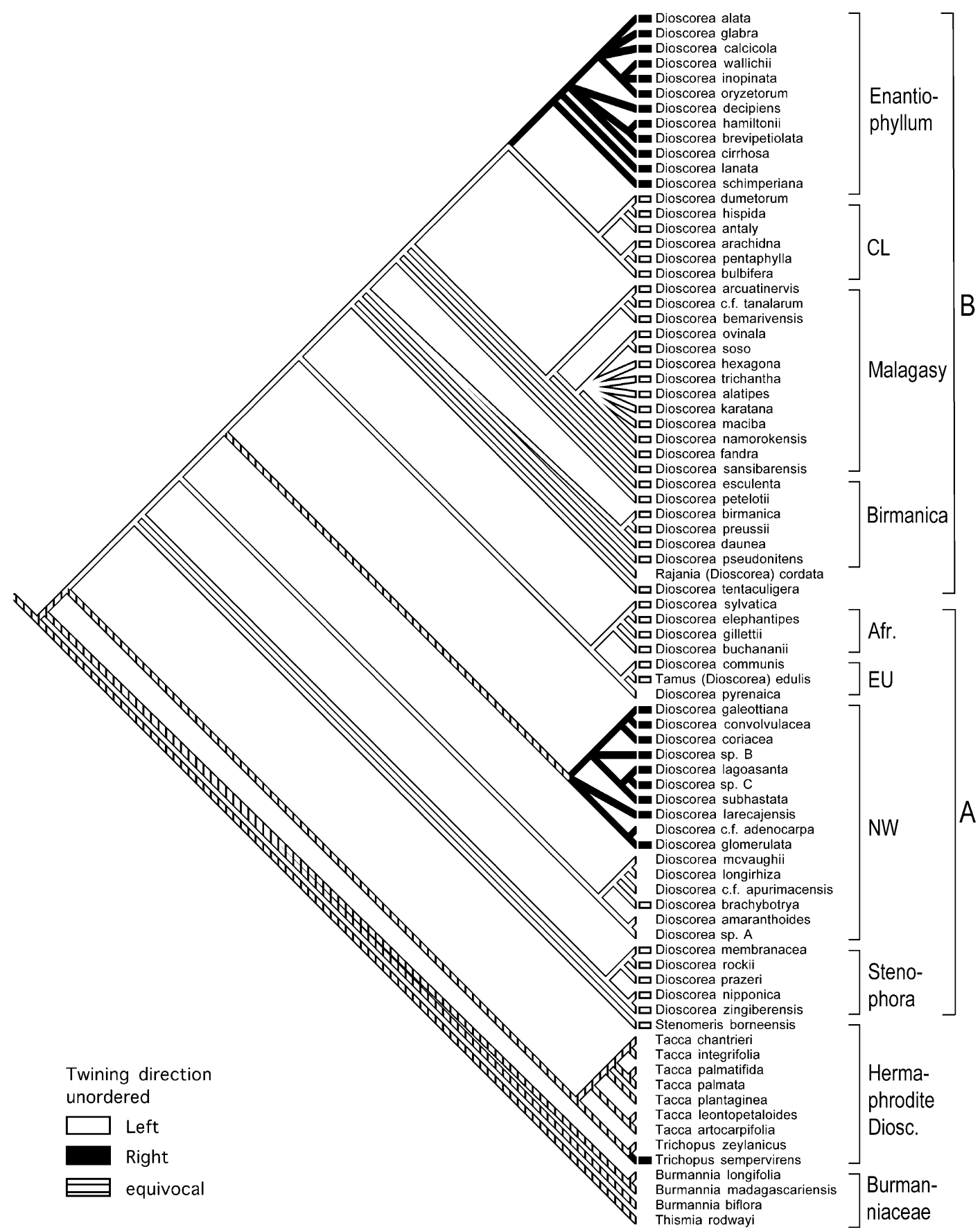

FIG. 4. Stem twining direction optimized onto one of the 15868 most parsimonious trees. Missing data are indicated by the lack of a shaded box at the branch tip.

(as measured by the short branch lengths) may also indicate that it may have been a relatively recent radiation or rate change, in which changes in life history associated with shifts into wetter zones and changes in flower and fruit morphology played key roles. This hypothesis needs to be evaluated with a better sampled and resolved tree.
The position of $D$. sansibarensis is unresolved. It is found in the lowland tropics of Madagascar and Africa, especially in riverine habitats. It has an unusual seed wing; the seed is winged all around the margin, but expanded towards the base and apex of the capsule locule, making it narrowly oblong (Wilkin 2001). Whether it is native to Madagscar is open to question; 


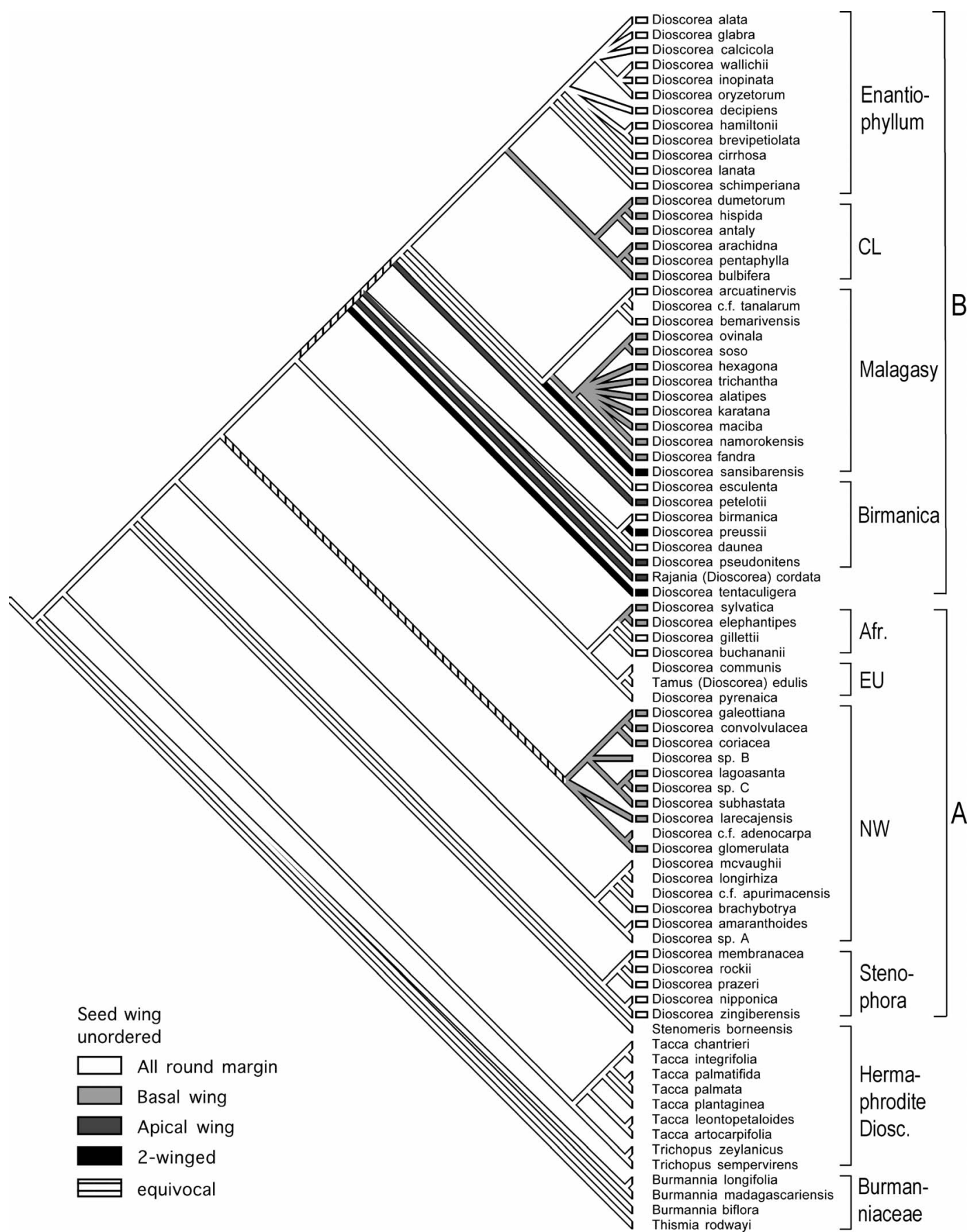

FIG. 5. Seed wing morphology optimized onto one of the 15868 most parsimonious trees. Missing data are indicated by the lack of a shaded box at the branch tip.

it is a bulbil-producer and thus easily dispersed. In the past it has been cultivated as both a famine food and a source of poison (Burkill 1985).

There is no support in Fig. 1 for the sectional classification used by Burkill and Perrier de la Bâthie (1950) for the Malagasy species. Dioscorea sects. Car- diocapsa Uline and Madagascarienses R. Knuth appear to represent a single taxon (one subclade). The other subclade includes the monotypic Dioscorea sect. Pachycapsa Burkill \& H. Perr. (D. ovinala, characterised by fruit with inflated, fleshy wings that only become dry shortly before dehiscence), D. sect. Campanuliflorae Burkill \& 
H. Perr. (e.g., D. maciba, with a campanulate torus), $D$. sect. Seriflorae Burkill \& H. Perr. (e.g., D. karatana, described as possessing claviform buds), and D. sect. Brachyandra Uline, in which the majority of species were placed. Species of $D$. sect. Brachyandra have a flat torus and a capsule in which the wings are thin and relatively dry throughout their development; D. fandra, D. soso, and D. trichantha were all placed there (Fig. 1). Although the limit of resolution of $r b c L$ and matK has been reached in this clade, it is nevertheless probable that the three smaller sections listed above nest within the larger D. sect. Brachyandra. Further support for this hypothesis is found in the existence of a Malagasy species with shallow bowl-shaped torus (Weber and Wilkin in prep.) intermediate in form between the flat disc of D. sect. Brachyandra and the campanulate torus found in D. sect. Seriflorae or Campanuliflorae. The topology of Fig. 1 in general, and this clade in particular, indicates that substantial simplification of the whole Knuth/Burkill infrageneric classification will be possible when an adequate number of species have been sampled.

Compound-leafed Taxa and their Allies. Although compound leaves have arisen at least twice in the Old World tropics (CL clade and D. bemarivensis in Madagascar) as well as in the New World, the majority of compound-leafed species are found in the CL clade. A previous study (Wilkin and Caddick 2000) using rbcL and morphology indicated that D. dumetorum and its allies with several veins per leaflet (D. sect. Lasiophyton) were sister to $D$. pentaphylla and its allies with one main vein per leaflet (D. sect. Botryosicyos), although $r b c L$ alone did not show this relationship. The two sections are recovered in the combined strict consensus tree (Fig. 1) as well-supported clades within the CL clade (BP 96 and 99, respectively). In the analysis of matK alone the two clades are sister with weak bootstrap support. It appears that mat $K$ is congruent with morphology for these taxa, but that there is insufficient variation in $r b c L$ to show their sister relationship.

Figure 1 indicates that entire-leafed species may be related to $D$. sect. Lasiophyton and D. sect. Botryosicyos. In the case of $D$. sect. Lasiophyton, D. antaly is the sister taxon with weak bootstrap support (BP 50). Dioscorea antaly is the only endemic Malagasy species not in the main Malagasy clade. It has always been thought to be unusual; it has unique branching tubers and a fruit thickened along its axis. Burkill and Perrier de la Bâthie (1950) separated it as D. sect. Xylinocapsa Burkill \& $\mathrm{H}$. Perr. It therefore appears that Madagascar has two endemic lineages of Dioscorea, one of which has radiated (the Malagasy clade) and one of which has not (D. antaly). D. sect. Botryosicyos has D. bulbifera as their sister species. Although this clade is not robust, it is present in the strict consensus tree obtained from $r b c L$ alone. Dioscorea bulbifera is unresolved at the base of a combined compound-leafed clade in the strict consensus tree obtained from matK alone. All of these six taxa have seeds winged at the base only (Fig. 5).

Enantiophyllum. This clade is congruent with past classifications; both Knuth (1924) and Burkill (1960) recognized the Old World right-twining species (Fig. 4) as D. sect. Enantiophyllum Uline. All of the species sampled (except the unusual Thai limestone endemic D. inopinata) also have opposite leaves, whereas the left-twiners are usually alternate. Prain and Burkill (1936) believed D. inopinata to be a hybrid between $D$. bulbifera and a right-twining species, but they may have been misled by its narrow, alternate leaves. The clade is clearly defined by right-twining stems and usually opposite leaves, but the limits of its ca. 80 species are often unclear. All of the species of this clade have putatively retained the plesiomorphic seed condition (winged all round the margin, Fig. 5), unlike many other B clade taxa of Dioscorea. African D. schimperiana, with its stellate hairs, appears to be sister to the remaining species in this clade. Similar stellate hairs are also found in four other African species and D. orbiculata Hook. f. from Asia, all of which are righttwiners. The African species with stellate hairs were placed in a separate section or sections by previous authors (e.g., D. sect Asterotricha Uline; Burkill 1960), but this is not supported by our results. Like the Malagasy clade, it appears from the low levels of molecular divergence that this group is a recent radiation or has a slower rate, but this needs further investigation.

The position of one species in this clade is of particular economic significance; D. alata, the winged yam, which is the most important cultivated yam in Asia. It has also been distributed westward and can be encountered in Africa and even the Americas. Prain and Burkill (1938) placed it in a group of species from Southeast Asia that share a flexuous male inflorescence. A recent AFLP study (Malapa et al. 2006) indicated that its affinities were with $D$. nummularia Lam., an edible species of the Malay Archipelago east to New Guinea. D. nummularia was thought to be a close relative of D. glabra by Prain and Burkill (1938). The sequence data used here produces a similar result; the species with a flexuous male inflorescence are represented by $D$. hamiltonii (with which $D$. persimilis, studied by Malapa et al. 2006, is synonymous) and $D$. brevipetiolata. These two species are resolved as sister species with BP 85 . Dioscorea alata, however, does not fall within this clade when either the Fuse and Tamura (2000) matK sequence or one generated in this study are used.

In overall terms, the phylogenetic trees presented and discussed here appear to provide a framework to guide further research on Dioscorea. Monophyletic taxa such as D. sects. Stenophora and Enantiophyllum and the Malagasy clade need further work to resolve both the 
limits of their species and the phylogenetic relationships between them. It is envisaged that this work will include both study of morphology and sequencing of at least one low-copy nuclear gene such as those used successfully in palms (e.g., Lewis and Doyle 2002). Research on the macromorphology of the Malagasy species is already well advanced, and a pilot study using ITS has been started for the genus. The taxon sampling will be substantially increased by adding New World taxa and gap-filling among the Old World groups, especially the main cultivated and edible taxa and their close relatives. The morphological character optimizations show that comparative studies need to be targeted towards underground parts and seeds to try to uncover homologous characters for systematic use.

ACKNOWLEDGEMENTS. The authors thank the staff of the Thai Royal Forest Department, especially Somran Suddee, Rachan Pooma, Voradol Chamchumroon, Thanongsak Jonganurak, and Juy from its herbarium, and also the Biology Department of Naresuan University. In Madagascar, the assistance of the Parc Botanique et Zoologique de Tsimbazaza, Departement des Eaux et Forets, Aire National pour la Gestion des Aires Proteges and Helene Ralimalalana is gratefully acknowledged. At RBG, Kew, the work could not have been completed without the help of Liz Caddick, Martyn Powell, Dion Devey, Jeff Joseph, Jim Clarkson, Olivier Maurin, Dave Springate, Nina Rönsted, Gerardo Salazar, Robyn Cowan, Laszlo Csiba, and Edith Kapinos among a cast of thousands in the Molecular Systematics Section. Thanks also to Gwil Lewis, Aaron Davis, Bill Baker, John Dransfield, and Owaldo Tellez-Valdez for collecting material, and Clive Foster, John Sitch, and Lin Jenkins for expert cultivation of living plants, and to Phillip Cribb for his helpful comments on an earlier version of this manuscript. The manuscript was substantially clarified and strengthened by two anonymous reviewers and the editors Alan Meerow and Pat Herendeen.

\section{LiTERATURE CiTED}

Allen, G. A, D. E. Soltis, and P. S. Soltis. 2003. Phylogeny and biogeography of Erythronium (Liliaceae) inferred from chloroplast matK and nuclear rDNA ITS sequences. Systematic Botany 28: 512-523

Bharathan, G., L. Raz, and P. Wilkin. 2001. The true yams, Dioscorea (Dioscoreaceae): phylogenetic analysis of chloroplast nucleotide sequences. P. 154 in Botany 2001: plants and people, Abstracts. [Albuquerque.] http://www.botany2001.org/ section12/abstracts/219.shtml

BuRKILL, I. H. 1939. Notes on the genus Dioscorea in the Belgian Congo. Bulletin du Jardin Botanique Belgique 15: 345-392.

_. 1951. Dioscoreaceae. Pp. 293-335 in Flora Malesiana, Series I, Vol. 4, ed. C. G. G. J van Steenis. Djakarta: Noordhoff-Kolff N.V.

- 1952. Testudinaria as a section of the genus Dioscorea. Journal of South African Botany 18: 177-191

- 1960. The organography and the evolution of the Dioscoreaceae, the family of the yams. Journal of the Linnean Society (Botany) 56: 319-412.

— and H. Perrier De la BÂthiE. 1950. Dioscoréacées, 44 famille in Flore de Madagascar et des Comores, ed. H. Humbert. Paris: Firmin-Didot et $\mathrm{C}^{\text {ie }}$.

BURKILL, H. M. 1985. The useful plants of west tropical Africa, Edition 2, Vol. 1. Kew: Royal Botanic Gardens.

Caddick, L. R., C. A. Furness, K. L. Stobart, and P. J. Rudall.
1998. Microsporogenesis and pollen morphology in Dioscoreales and allied taxa. Grana 37: 321-336.

— CHASE. 2002b. Phylogenetics of Dioscoreales Based on Combined Analyses of Morphological and Molecular Data. Botanical Journal of the Linnean Society 138: 123-144.

- P. Wilkin, P. J. Rudall, T. A. J. Hedderson, and M. W. CHASE. 2002a. Yams reclassified: a recircumscription of Dioscoreaceae and Dioscoreales. Taxon 51: 103-114.

CAMERON, K. M., M. W. Chase, W. R. ANDERSON, and H. G. Hills. 2001. Molecular systematics of Malphigiaceae: evidence from plastid $r b c L$ and matK sequences. American Journal of Botany 88: 1847-1862.

ChASE, M. W. 2004. Monocot relationships: an overview. American Journal of Botany 91: 1645-1655.

, and H. G. HiLls. 1991. Silica gel: an ideal material for field preservation of leaf samples for DNA studies. Taxon 40: 215220.

— S. Knapp, A. V. CoX, J. J. ClaRkson, Y. BUtSKo, J. Joseph, V. SAVOLAINEN, and A. S. PAROKONNY. 2003. Molecular systematics, GISH and the origin of hybrid taxa in Nicotiana (Solanaceae). Annals of Botany 92: 107-127.

COURSEY, D. G. 1967. Yams: an account of the nature, origins, cultivation and utilisation of the useful members of the Dioscoreaceae. London: Longmans.

Cuénoud P., V. Savolainen, L. W. Chatrou, M. Powell, R. J. GRAYER, and M. W. CHASE. 2002. Molecular phylogenetics of Caryophyllales based on nuclear $18 \mathrm{~S}$ rDNA and plastid $r b c L$, atpB, and matK DNA sequences. American Journal of Botany 89: 132-144.

Dahlgren R. M. T., H. T. Clifford, and P. F. Yeo. 1985. The families of the monocotyledons. Berlin: Springer Verlag.

DiNG, Z. and M. G. GILBERT. 2000. Dioscoreaceae. Pp. 276-296 in Flora of China, Vol. 24, Flagellariaceae through Marantaceae, eds Z. Wu and P. H. Raven. Science Press: Beijing, and Missouri Botanical Garden Press: St. Louis.

DoYLE, J. J. and J. L. DoYLE. 1987. A rapid DNA isolation procedure for small quantities of fresh leaf tissue. Phytochemical Bulletin 19: 11-15.

Felsenstein, J. 1985. Confidence limits on phylogenies: an approach using the bootstrap. Evolution 39: 783-791.

Fuse, S. and M. N. TAMURA. 2000. A phylogenetic analysis of the plastid matK gene with emphasis on Melanthiaceae sensu lato. Plant Biology 2: 415-427.

GE, S., A. LI, B.-R. Lu, S. Z. ZHANG, and D.-Y. Hong. 2002. A phylogeny of the rice tribe Oryzeae (Poaceae) based on matK sequence data. American Journal of Botany 89: 1967-1972.

Goldblatt, P., V. Savolainen, O. Porteous, I. Sostaric, M. PowelL, G. ReEves, J. C. Manning, T. G. BarRaClough, and M. W. CHASE 2002. Radiation in the Cape flora and the phylogeny of peacock irises Moraea (Iridaceae) based on four plastid DNA regions. Molecular Phylogenetics and Evolution 25: 341360.

Gravendeel, B., M. W. Chase, E. F. De Vogel, M. C. Roos, T. H. M. MES, and K. BACHMANN. 2001. Molecular phylogeny of Coelogyne (Epidendroideae: Orchidaceae) based on plastid RFLPs, mat $K$, and nuclear ribosomal ITS sequences: evidence for polyphyly. American Journal of Botany 88: 1915-1927.

Huber, H. 1969. Die Samenmerkmale und Verwandtschaftsverhältnisse der Liliifloren. Mitteilungen aus dem Botanischen Staatssammlung München 8: 219-538.

- 1998. Dioscoreaceae. Pp. 216-235 in The families and genera of vascular plants, Volume III, Monocotyledons, Lilianae (except Orchidaceae), ed. K. Kubitzki. Berlin: Springer-Verlag.

JONKER, F. P. 1938. A monograph of the Burmanniaceae. Utrecht: Kemink en Zoon N.V.

KNuth, R. 1924. Dioscoreaceae. Pp. 1-387 in Das Pflanzenreich, 87 
(IV. 43), ed. H. G. A. Engler. Leipzig: H. R. Engelmann (J. Cramer).

KUBITZKI, K. 1998. The families and genera of vascular plants, Volume III, Monocotyledons, Lilianae (except Orchidaceae). Berlin: Springer Verlag.

KuntH, C. S. 1850. Enumeratio Plantarum Volume 5. Stuttgart \& Tubingen: J.G. Cottus.

LAMB FrYE, A. S. and K. A. KRON. 2003. rbcL phylogeny and character evolution in Polygonaceae. Systematic Botany 28: 326332.

LewIS, C. E. and J. J. DoyLE. 2002. A phylogenetic analysis of palm tribe Areceae using two low-copy nuclear genes. Plant Systematics and Evolution 236: 1-17.

MAaS-VAN DE KAMER, H. 1998. Burmanniaceae. Pp. 154-164 in The families and genera of vascular plants, Volume III, Monocotyledons, Lilianae (except Orchidaceae), ed. K. Kubitzki. Berlin: Springer-Verlag.

MAdDISON, W. and D. MAdDison. 2002. MacClade 4.05 software. Sunderland: Sinauer Associates.

Malapa R., Noyer J. L., Marchand J. L. and Lebot V. 2006. Genetic relationship between $D$. alata and D. nummularia Lam. as explained with AFLP markers. Pp. 239-268 in Darwin's Harvest-New Approaches to the Origins, Evolution, and Conservation of Crops: A Molecular Approach, eds T. J. Motley, N. J. C. Zerega \& H. G. Cross. Columbia University Press, New York.

Manos, P. S., R. E. Miller, and P. Wilkin. 2001. Phylogenetic analysis of Ipomoea, Argyreia, Stictocardia and Turbina suggests a generalized model of morphological evolution in morning glories. Systematic Botany 26: 585-602.

MiÈGE, J. 1968. Dioscoreaceae. Pp. 144-154 in Flora of West Tropical Africa, Second Edition, ed. F. N. Hepper. London: Crown Agents.

— and SebSEBe D. 1998. Dioscoreaceae. Pp 55-62 in Flora of Ethiopia and Eritrea, Vol. 6, Hydrocharitaceae to Araceae, eds. S. Edwards, Sebsebe D. and I. Hedberg. Addis Ababa: The National Herbarium, Biology Department, Science Faculty, Addis Ababa University; Uppsala: Department of Systematic Botany, Uppsala University.

Milne-ReDHEAD, E. 1975. Dioscoreaceae in Flora of Tropical East Africa, ed. R. M. Polhill. London: Crown Agents.

N'KOUNKOU, J. S. (1993). Les Dioscoreaceae du Congo. Fragmenta Floristica Geobotanica, Supplementa 2: 139-182.

Perret, M., A. Chautems, R. Sitchiger, G. Kite, and V. SavoLAINEN. 2003. Systematics and evolution of tribe Sinningieae (Gesneriaceae): evidence from phylogenetic analyses of six plastid DNA regions and nuclear ncpGS. American Journal of Botany 90: 445-460.

Prain, D. and I. H. Burkill. 1936. An account of the genus Dios- corea in the East, Part 1: The species which twine to the left. Annals of the Royal Botanic Gardens, Calcutta 14: 1-210.

and-1938. An account of the genus Dioscorea in the East, Part 2: The species which twine to the right. Annals of the Royal Botanic Gardens, Calcutta 14: 211-528.

Reeves, G., M. W. Chase, P. Goldblatt, P. Rudall, M. F. Fay, A. V. CoX, B. Lejeune, and T. SouZA-ChIES. 2001. Molecular systematics of Iridaceae: evidence from four plastid DNA regions. American Journal of Botany 88: 2074-2087.

RichaRDS, A. J. 1986. Plant breeding systems. London: George Unwin \& Allen.

Salazar, G. A., M. W. Chase, M. A. Soto Arenas, and M. INGROUILLE. 2003. Phylogenetics of Cranichideae with emphasis on Spiranthinae (Orchidaceae, Orchidoideae): evidence from plastid and nuclear DNA sequences. American Journal of Botany 90: 777-795.

Simpson, D. A., C. A. Furness, T. R. Hodkinson, A. M. Muasya, and M. W. CHASE. 2003. Phylogenetic relationships in Cyperaceae subfamily Mapanioideae inferred from pollen and plastid DNA sequence data. American Journal of Botany 90: 1071-1086.

Sosa, V., B. G. SChUbert, and A. GÓmez-Pompa. 1987. Flora de Veracruz: Dioscoreaceae. Xalapa: Instituto Nacional de Investigaciones Sobre Recursos Bioticos.

SWOFFORD, D. L. 2001. PAUP*: Phylogenetic analysis using Parsimony (*and other methods) version 4.0b10. Sunderland: Sinauer Associates.

Tellez V., O and B. G. Schubert. 1994. Dioscoreaceae. Pp.54-65 in Flora Mesoamericana Volumen 6, Alismataceae a Cyperaceae, eds. G. Davidse, M. Sousa S. and A. O. Chater. Mexico D.F. Universidad Nacional Autonoma de Mexico.

ULINE, E. B. 1898. Eine monographie de Dioscoreaceen. Botanische Jahrbucher 25: 126-165.

WILKIN, P. 1999. A revision of the compound leaved yams of Africa. Kew Bulletin. 54: 19-39.

- 2001. Yams of south-central Africa. Kew Bulletin 56: 361404.

.and L. R. CADDICK. 2000. Palaeotropical compound-leaved yams (Dioscorea; Dioscoreaceae): monophyly and relationships. Pp. 494-500 in Monocots: systematics and evolution, eds. K. L. Wilson and D. A. Morrison. Melbourne: CSIRO. , K. K. DAvis, P. Schols, and C. A. Furness. 2002. Dioscorea ridleyi Prain \& Burkill and D. palawana Prain \& Burkill: new systematic data on two rare South-East Asian yam species Kew Bulletin 57: 885-900.

Whitten, M. W., N. H. Williams, and M. W. Chase. 2000. Subtribal and generic relationships of Maxillarieae (Orchidaceae) with emphasis on Stanhopeinae: combined molecular evidence. American Journal of Botany 87: 1842-1856. 